\title{
VIETNAMESE ENTERPRISES' CAPACITY TO COPE WITH CHALLENGES OF INTELLECTUAL PROPERTY IN THE TRANS-PACIFIC PARTNERSHIP
}

\author{
Dr. Nguyen Thi Bich Ngoc* \& Dr. Ho Thuy Ngoc ${ }^{* *}$
}

Vietnam is said to be the biggest winner from the Trans-Pacific Partnership (TPP $)^{l}$. Besides promising benefits, many challenges can be seen. The area providing many obstacles for both legal framework and enterprises is intellectual property. TPP shall push the intellectual property legal system of Vietnam to change to meet higher standards. How higher they are? What actions should be done to realize the requirements in intellectual property area? The challenges in the field do not involve only Vietnamese government, but also business sectors. How ready are they in terms of intellectual property? In order to answer the above questions, the paper used data obtained from the survey conducted in 2015 in which we interviewed 450 enterprises in Hanoi, Ho Chi Minh City, Da Nang and Quang Ninh. Questionnaires were prepared and sent to the said enterprises by post mails and emails. The Statistical Package for the Social Sciences was used to support the analyses. The paper highlights two legal issues which should be addressed to meet TPP requirements of intellectual property. The paper analyzes Vietnamese enterprises' capacity of research and development in order to work out what the Government should do to support them to take advantage of their active roles in the market.

INTRODUCTION

I. LITERATURE REVIEW ON INTELLECTUAL PROPERTY IN THE TPP TO

VIETNAM.

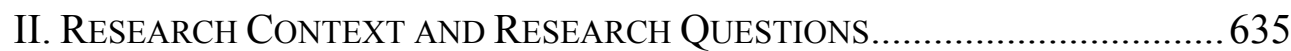

III. DATA AND METHODOLOGIES .......................................................6 636

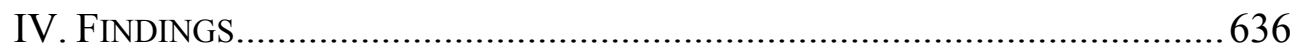

A. $\quad$ Enterprises and the Need of Intellectual Property Reception .. 636

B. Enterprises and Outside Support for Intellectual Property

Reception

CONCLUSION.

\footnotetext{
* Dr. Nguyen Thi Bich Ngoc, Head of Graduate Department, Ho Chi Minh City University of Law, Vietnam. Research fields: Intellectual Property Law and International Private Law.

${ }^{* *}$ Dr. Associate Prof. Ho Thuy Ngoc, Corresponding author, Dean of International Education Department, Foreign Trade University, Vietnam. Research fields: Intellectual Property and Green Economy.

${ }^{1}$ Ed Gerwin, TPP and the Benefits of Freer Trade for Vietnam: Some Lessons from US Free Trade Agreements, Progressive Policy Institute 1 (2015).
} 


\section{INTRODUCTION}

The Trans-Pacific Partnership (TPP) establishes new rules to reduce trade and investment barriers among members including Vietnam. Vietnam is said to be the biggest winner from the TPP. Besides promising benefits, many challenges can be seen. The area providing many obstacles for both legal framework and enterprises is intellectual property. The TPP shall push the intellectual property legal system of Vietnam to change to meet higher standards. The TPP also creates opportunities for Vietnamese enterprises in intellectual property if they are able to catch them.

A large body of academic research studies the TPP from various of perspectives, the benefits and the challenges to members' economies and non-member economies. Some works have shown that intellectual property is considered to be the most concerned area for Vietnam when joining the TPP. There are a few researches at firm-based level on the capacity to cope with challenges in intellectual property in the TPP. Our study attempts to fill in this gap in the literature by the assumption that Vietnamese enterprises are aware of the necessity of intellectual property development but their capacity is limited. The paper is designed to test which support is effective to the enterprises' reception of intellectual property due to the trade and investment environment in the TPP.

\section{LITERATURE REVIEW ON INTELLECTUAL PROPERTY IN THE TPP TO VIETNAM}

The Trans-Pacific Partnership (TPP) is said to be the largest free trade agreement in history. Hence, there have been many studies on it even since it was a leaked version. The studies aim to reveal TPP from substantive issues to impact evaluation. There are three critical areas of TPP literature: economic and trade impact, geostrategic implications and nontrade related issues $^{2}$. Csilla Lakatos et al (2016) not only show the main features of the TPP, the difference of the TPP from traditional free trade agreements, but also point the potential macroeconomic implications of the TPP ${ }^{3}$.

Of interest of many countries, a large part of works (Antonio C. Hsiang 2014; Sheng-Yu Chien et al 2013; Thomas L. Friedman, 2014) focused on TPP analysis as a whole to work out its benefits to countries including

\footnotetext{
${ }^{2}$ Thomas R. Goggin, The Trans-Pacific Partnership: Expanding International Regimes, CUNY Academic Works 12 (2015).

${ }^{3}$ Csilla Lakatos et al, Potential Macroeconomic Implications of the Trans-Pacific Partnership, Global Economic Prospects 219-255 (January 2016).
} 
impact on overall member countries, individual member countries and nonmembers. ${ }^{4}$ Although there have been different ways of approach, common views can be seen that TPP contains provisions that would produce profound geo-political and economic changes. Antonia C. Hsiang (2014) and Ernest Z. Bower (2012) ${ }^{5}$ confirms that the United States has all the tools to build an enduring and sustainable strategy for engagement in the Asia Pacific and makes sure that the TPP avoids weakening or dividing ASEAN.

As for Vietnam, many studies have pointed out that Vietnam is poised to be TPP's biggest winner among all member countries. Ed Gerwin (2015), Kent Hughes and Anh Nguyen (2015) even estimate that export from Vietnam can increase 89.1 billion of 2007 USD in 2025 (37.3\% from baseline). ${ }^{6}$ TPP membership also will make Vietnam more attractive for investment. Besides, some works show that with the provisions going well beyond WTO standards, the TPP has created many obstacles for both legal framework and enterprises. Intellectual property is considered to be the most concerned area for Vietnam. A series of works discuss risks and challenges that Vietnam shall face in intellectual property when joining the TPP. Tran Van Hai (2016) addressed three typical barriers in the field which are barrier for trademark, for geographical indication, generic medicine access. ${ }^{7}$ Kilic B. \& Mabarduk P. (2011) worked out 11 differences in intellectual property regulations between the TPP and Vietnamese intellectual property law. ${ }^{8}$ Such barriers are not only faced by Vietnam, but also other member countries. Similar arguments can be found in Carlos A. Primo Brage (2016), Baker BK (2016). ${ }^{9}$

To the best of our knowledge, a few studies have looked at the capacities to cope with the mentioned above challenges of enterprises

\footnotetext{
${ }^{4}$ Antonio C. Hsiang, TPP as Grand Strategy: Latin American Perspectives, Paper Presented at FLACSO-ISA Joint International Conference (Buenos Aires, Argentina, July 23-25, 2014); Sheng-Yu, Chien et al, The Impacts of the Trans-Pacific Strategic Economic Partnership Agreement on Taiwanese Economy, National Cheng Chi University (2013); Thomas L.Friedman, Don't Just Do Something Sit There, New YoRK TiMES, Feb. 25, 2014.

${ }^{5}$ Ernest Z. Bower, US Strategic Alignment: Squaring Trade and Grand Strategy in Asia, Center for Strategic and International Studies, March 30, 2012.

${ }^{6}$ Ed Gerwin, TPP and the Benefits of Freer Trade for Vietnam: Some Lessons from US Free Trade Agreements, Progressive Policy Institute, at 1 (2015); Kent Hughes and Anh Nguyen, Vietnam Takes on the Trans-Pacific Partnership, Wilson Briefs, Wilson Center 2-3 (2015).

${ }^{7}$ Tran Van Hai, Khắc phuc một số rào cản về sở hưu trí tuệ mà các doanh nghiệp Việt Nam sẽ gặp phải khi TPP được vận hành, 76-77 Tạp chí Thương hiệu Việt 19-325(2016).

${ }^{8}$ Kilic B. \& Mabarduk P., Phân tích so sánh Bản chào của Hoa Kỳ trong TPFTA về Quyền Sở hữu trí tuệ và Pháp luật Việt Nam, Public Citizen (June 2011).

9 Baker BK, Trans-Pacific Partnership Provisions in Intellectual Property, Transparency, and Investment Chapters Threaten Access to Medicines in the US and Elsewhere, 13(3) PLoS Med e1001970 (2016). doi:10.1371/journal.pmed.1001970.
} 
in Vietnam, important players in the trade environment created by the TPP.

\section{RESEARCH CONTEXT AND RESEARCH QUESTIONS}

The provisions in the TPP create the common regional framework for intellectual property. Although TPP's intellectual property chapter includes important objectives and principles from the World Trade Organization Agreement on Trade-Related Aspects of Intellectual Property Rights (TRIPS), many provisions are well beyond WTO standards. Therefore, Vietnamese legislations are required to change. For example, Article 18.18 prohibits a party require as a condition of registration that a sign be visually perceptible nor to deny registration of a trademark only on the ground that the sign of which it is composed is a sound. Besides, the article encourages each party to make best efforts to register scent marks. The Provision is acceptable to many members as they have accepted non-visible trademarks like sound marks, olfactory marks, taste marks. However, Article 72.1 existing Intellectual Property Law in Vietnam just accepts visible trademarks, which creates barriers to enterprises in cosmetics, recordings, etc.

Some provisions not only lead to the legislative modification but also provide heavy burden on Vietnamese enterprises due to their capacities. Article 18.48 requires each party to make available an adjustment of the patent term to compensate patent owner for unreasonable curtailment of the effective patent term, which results in the patent term longer than 20 years. In Vietnam, 20 years is the maximum time for patent protection, regardless of unreasonable curtailment. Besides the modification in law, Vietnamese enterprises are prevented from patent access, especially in pharmaceutical area.

Vietnam is seeing increased levels of foreign direct investment in anticipation of the TPP ${ }^{10}$, resulting in the opportunity for Vietnamese enterprises to receive intellectual property flow from business partners by assignment and/or licensing. Is it advantage or disadvantage for the enterprises? The answer depends on their capacity and their willingness of reception.

This analysis aims to address the following questions:

- What is Vietnamese enterprises' understanding towards intellectual property stipulated in the TPP?

\footnotetext{
${ }^{10}$ Ed Gerwin, TPP and the Benefits of Freer Trade for Vietnam: Some Lessons from Ú Free Trade Agreements, Progressive Policy Institute 3 (2015).
} 
- What is Vietnamese enterprises' capacity in intellectual property development and reception?

- What solutions should be suggested to improve the capacity for Vietnamese enterprises to cope with the challenges?

\section{DATA AND METHODOLOGIES}

We used data obtained from the survey conducted in 2015 in which we interviewed 450 enterprises in Hanoi, Ho Chi Minh City, Da Nang and Quang Ninh. Hanoi and Ho Chi Minh City are the two biggest centers of economy, education and technology in the North and the South of the country so we assume that enterprises there shall be leaders in intellectual property creation. Da Nang and Quang Ninh are situated in the center and northern center of Vietnam and are considered to be dynamic in technological areas. Questionnaires were prepared and sent to the said enterprises by post mails and emails.

The number of enterprises in interview was $26.4 \%$ in Ho Chi Minh City, $62.9 \%$ in Hanoi and $10.6 \%$ in Quang Ninh and $10.6 \%$ in Da Nang. $75.3 \%$ of enterprises interviewed situate in urban area; $20.7 \%$ of enterprises interviewed are in industrial zone; $2.7 \%$ are in hitech parks and only $1.3 \%$ are in processing zone.

To ensure the accuracy of the information collected, we arranged interviews with management boards or heads of R\&D departments of 20 outstanding enterprises in the fields.

The paper used data obtained from the National Office of Intellectual Property to have an overview of Vietnamese enterprises in intellectual property creation and exploitation in Vietnam.

First, bivariate relationships among variables were explored via correlation analysis. Then, multiple regression analyses were performed to provide quantitative view. The Statistical Package for the Social Sciences (SPSS) was used to support the analyses.

\section{FINDINGS}

\section{A. Enterprises and the Need of Intellectual Property Reception}

The study looks at factors creating competitiveness for the interviewed enterprises and the result is as stated in the Table 1. 
Table 1 Factors Contributing to the Competitiveness.

\begin{tabular}{lll}
\hline & Factors contributing to the competitiveness & Percentage \\
\hline 1 & Cheap labor & 3.94 \\
2 & Product & 4.63 \\
3 & Distribution channel & 14.58 \\
4 & Quality & 20.14 \\
5 & Package & 18.75 \\
6 & Lower price & 19.68 \\
7 & Geographical advantage & 7.64 \\
8 & Others & 10.65 \\
\hline
\end{tabular}

It can be seen that the competitiveness mostly comes from factors relating to the intellectual property elements, which are quality, package, lower price. More than $60 \%$ of the enterprises in the survey share the view. Hence, it is concluded that intellectual property plays an important role to the development of Vietnamese enterprises. What is the capacity of Vietnamese enterprises in the creation and exploitation of intellectual property? The answer can be found by looking at the R\&D activities in the enterprises. The survey has shown that more than $50 \%$ of the enterprises rely on their own in the process of intellectual property creation process, resulting in an understandable fact that $23.84 \%$ said that their $R \& D$ is not successful. The role of consulting center as intermediate party is reflected vague in the survey.

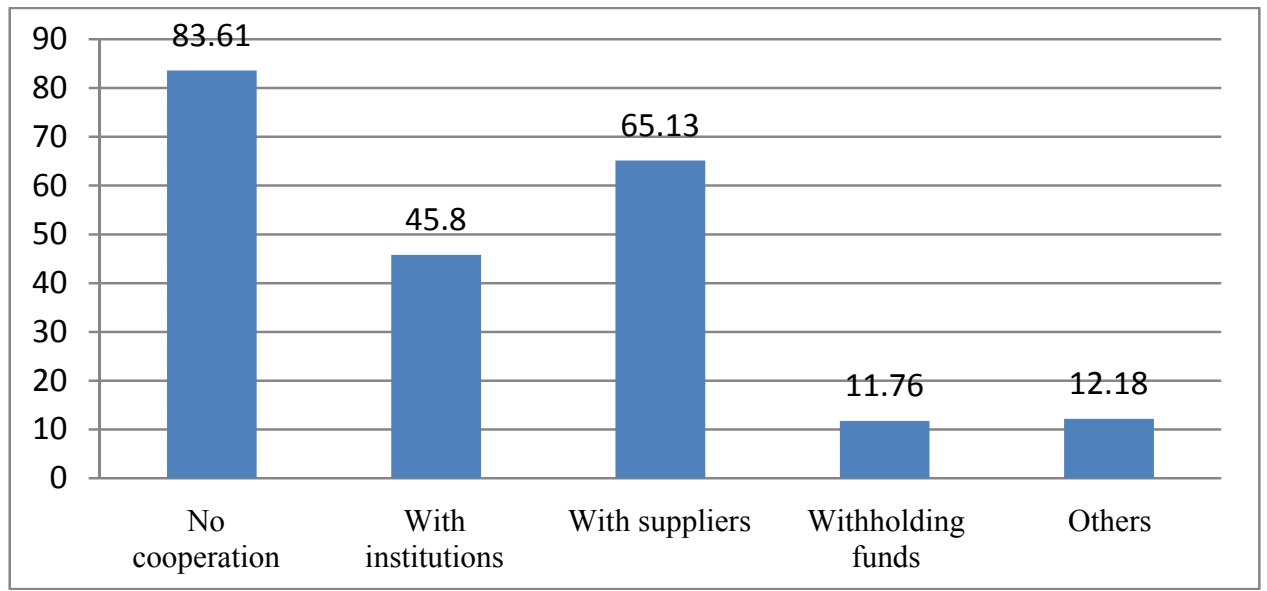

Figure 1. R\&D Cooperation Channel in Surveyed Enterprises.

Figure 1 shows $83.61 \%$ enterprises has no cooperation in R\&D. The cooperation with suppliers can be considered the second choice for them to create the intellectual property. $45.8 \%$ of the cooperation comes from 
research institutions, which can be seen a good signal as the link used to be weak before.

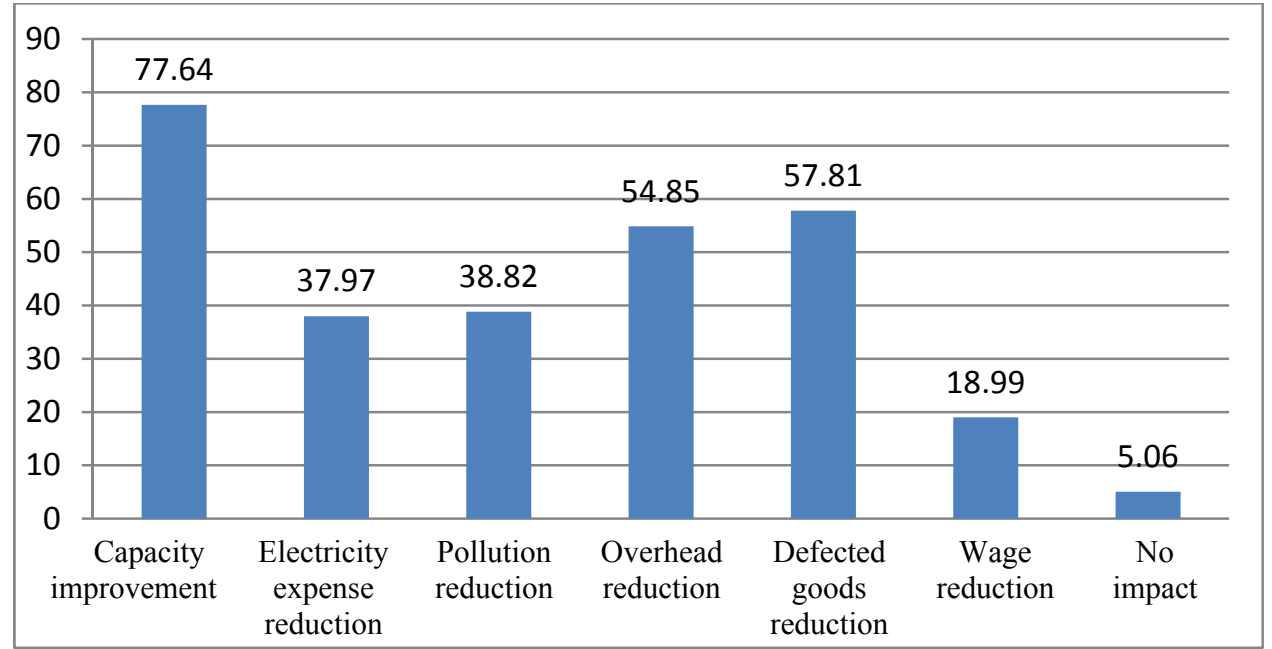

Figure 2. R\&D Impact on the Performance of the Enterprises Interviewed.

Figure 2 has shown the impact of R\&D activities on the performance of enterprises in the survey. Despite of being aware of the importance of $R \& D$ and having invested in $R \& D$, the enterprises own not so much intellectual assets (see Table 2).

Table 2 Number of Kinds of Intellectual Assets in the Enterprises Interviewed.

\begin{tabular}{lllll}
\hline & None & \multicolumn{3}{c}{ Number of kinds of intellectual assets } \\
\cline { 3 - 5 } & & 1 & 2 & More than 2 \\
\hline Patent & 88.19 & 6.25 & 1.16 & 4.4 \\
Design & 87.96 & 8.56 & 1.39 & 2.09 \\
Trademark & 70.83 & 20.6 & 3.24 & 5.33 \\
Trade secret & 93.98 & 5.32 & 0 & 0.7 \\
Geographical indication & 98.15 & 1.85 & 0 & 0 \\
Copyright & 92.13 & 6.94 & 0.46 & 0.47 \\
\hline
\end{tabular}

What is the reason behind the fact? It is admitted by the managers that their R\&D activities are not as efficient as expected or complicated administrative issues prevent them from registration of intellectual assets created or they do not realize the necessity of the registration. It also can be seen that trademark is the most popular intellectual asset registered by the enterprises. Some have more than 2 trademarks, even 15 to 20 trademarks. Table 3 explains the difficulties for the enterprises in development of intellectual assets. 
Table 3 The Difficulties for the Enterprises Interviewed in Development of Intellectual Assets.

\begin{tabular}{lll}
\hline & Mean & Standard deviation \\
\hline Lack of capital & 2.50 & 1.92 \\
Lack of human resource & 2.29 & 1.91 \\
Risk of R\&D investment & 2.28 & 1.80 \\
Inefficient protection of Intellectual assets & 2.24 & 1.79 \\
Lack of information of technology market & 2.03 & 1.74 \\
Difficulties in finding materials for new technology & 2.01 & 1.75 \\
Ease of imitation of competitors' products & 1.93 & 1.79 \\
\hline
\end{tabular}

Lack of capital is always referred to the most common difficulty (2.50). Good signal is that this is not considered to be impossible to overcome.

\section{B. Enterprises and Outside Support for Intellectual Property Reception}

Table 4 proves that business partners are vital sources to motivate enterprises to receive intellectual assets. The role of research institutes can be seen modest. The support from authorities is weak as well.

Table 4 Outside Support for Enterprises in Intellectual Property Development.

\begin{tabular}{lll}
\hline Source of support & Support/total enterprises & Support/enterprises having support \\
\hline Local authorities & 21.53 & 31.31 \\
Research management authorities & 20.37 & 29.63 \\
Business partners & 47.92 & 69.70 \\
Non-governmental organizations & 18.06 & 26.26 \\
Research institutes & 18.52 & 26.94 \\
Investment funds & 10.19 & 14.81 \\
Technology conselling & 29.63 & 43.10 \\
organizations & 31.02 & 45.12 \\
Associations & 13.6 & 19.87 \\
Others & &
\end{tabular}

It is proven here that there is a strong linkage between renovation and outside supports (authorities, business partners, research institutes). Also, customers' requirements and authorities' regulations are two outstanding determinants to push the intellectual property reception. Therefore, it is recommended for the government to develop these links and to erase obstacles which weaken such links.

It is found in this study that pressure from existing environment relating friendly - environmental related certificates is positively associated with intellectual asset reception motivation in Vietnamese enterprises. The government should take advantage of such pressure to encourage enterprises to invest resources in the development of such assets. 
CONCLUSION

This study has two main limitations. First, it relies on a cross-sectional survey, therefore, causal relationships among variables cannot be confirmed. Second, measures of determinants are still based on subjective assessment of managers in the enterprises. Future research could address these weaknesses by including objective measures of determinants and conducting longitudinal studies.

Despite all the limitations, results of this study still advance our knowledge of Vietnamese enterprises' capacities to grasp the opportunities in intellectual property area brought by Vietnam's membership in the TPP. The study has provided some important implication for enterprises' managers and for policy makers as well. 